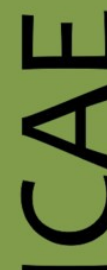

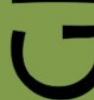

ex Instituto Archaeologico Universitatis de Rolando Eötvös nominatae

O

$\overrightarrow{0}$

山

$\leftarrow$

I

$\cup$

ه

$\leftarrow$

u

Ш

Z

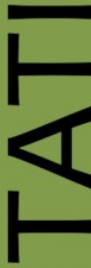

œ

ш

n

n

$\varnothing$
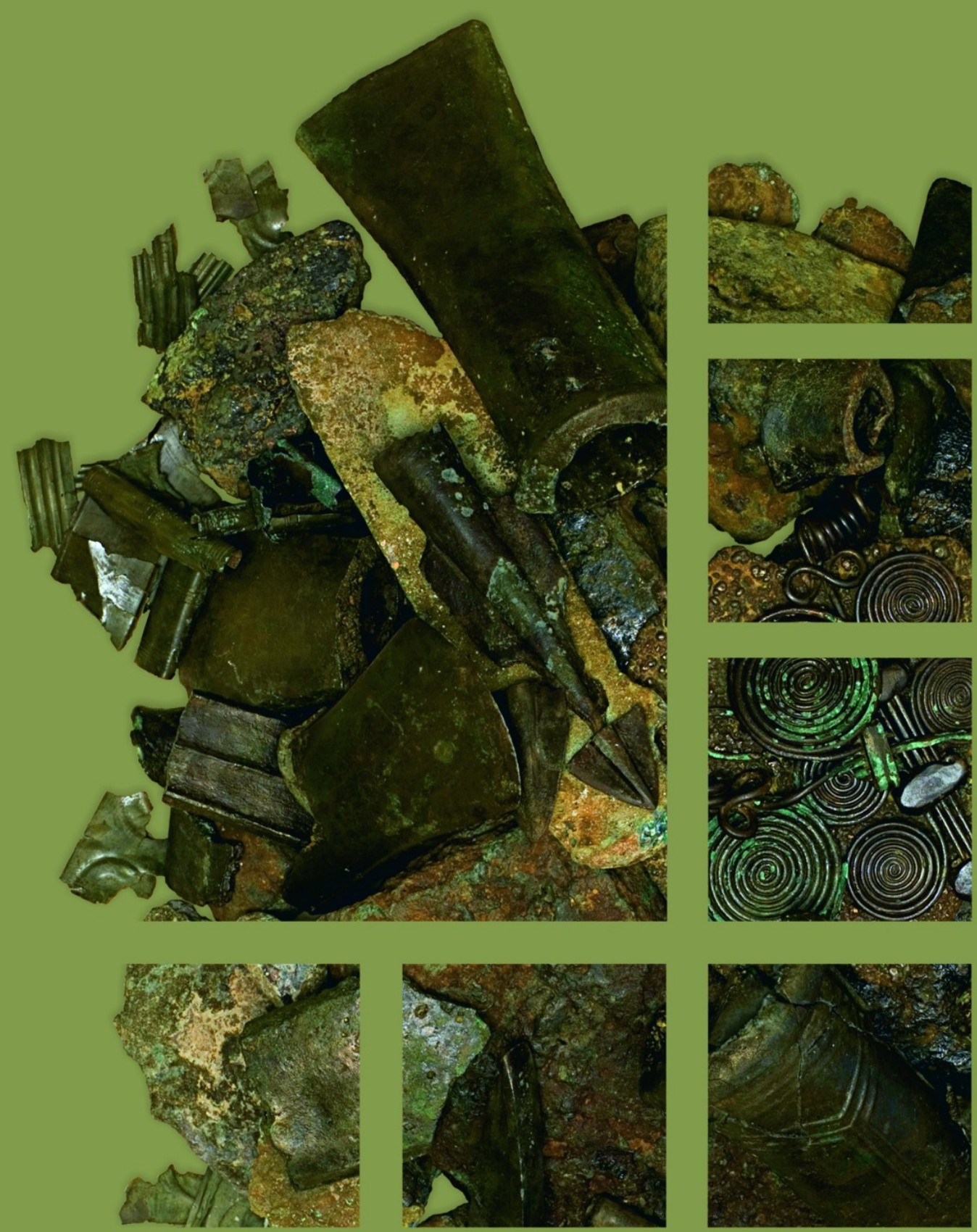


\section{Dissertationes Archaeologicae ex Instituto Archaeologico}

Universitatis de Rolando Eötvös nominatae Ser. 3. No. 2.

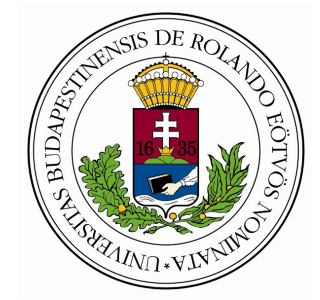

Budapest 2014 
Dissertationes Archaeologicae ex Instituto Archaeologico Universitatis de Rolando Eötvös nominatae

Ser. 3. No. 2.

Editor-in-chief:

DÁvid BARTus

Editorial board:

LÁsZló BARTOSIEWICZ

LÁSZLÓ BORHY

IsTVÁN FELD

GÁBOR KALLA

PÁL RACZKY

MiKLÓs SzABÓ

TIVADAR VIDA

Technical editors:

DÁvid BARTus

GÁBOR VÁCZI

ANDRÁs BÖDŐCS

DÁNIEL SZABÓ

Proofreading:

SZILVIA SzÖLLősI

Available online at http://dissarch.elte.hu Contact: dissarch@btk.elte.hu

$$
\begin{aligned}
& \text { PUBLIC } \\
& \text { KNOWLEDGE } \\
& \text { PROJECT }
\end{aligned}
$$

(c) Eötvös Loránd University, Institute of Archaeological Sciences

Budapest 2014 


\section{Contents}

\section{SElected PAPERS OF THE XI. Hungarian CONFERENCE on Classical Studies}

Ferenc BARNA

Venus mit Waffen. Die Darstellungen und die Rolle der Göttin in der Münzpropaganda

der Zeit der Soldatenkaiser (235-284 n. Chr.)

Dénes GABLER

A belsó vámok szerepe a rajnai és a dunai provinciák importált kerámiaspektrumában

Lajos MATHÉDESZ

Római bélyeges téglák a komáromi Duna Menti Múzeum gyújteményében

Katalin OtTOMÁNYI

Újabb római vicusok Aquincum territoriumán

Eszter SÜVEGH

Hellenistic grotesque terracotta figurines. Problems of iconographical interpretation

András SzABó

Some notes on the rings with sacred inscriptions from Pannonia

István VIDA

The coinage of Flavia Maxima Helena

\section{Articles}

Gábor TARBAY

Late Bronze Age depot from the foothills of the Pilis Mountains

Csilla SÁRó

Roman brooches from Paks-Gyapa - Rosti-puszta

András BöDőcs - Gábor KovÁcs - Krisztián ANDERKó

The impact of the roman agriculture on the territory of Savaria

Lajos JuHÁsz

Two new Roman bronzes with Suebian nodus from Brigetio

\section{FIELD REPORTS}

Zsolt MESTER - Norbert FARAGó - Attila KirÁLy

The first in situ Old Stone Age assemblage from the Rába Valley, Northwestern Hungary

Pál RACZky - Alexandra ANDERs - Norbert FARAgó - Gábor MÁRKus

Short report on the 2014 excavations at Polgár-Csőszhalom 
Preliminary Report on the first season of fieldwork in Berettyóúffalu-Szilhalom

Márton SzILÁgyi - András FüZESI - Attila VIRÁG - Mihály GASPARIK

A Palaeolithic mammoth bone deposit and a Late Copper Age Baden settlement and enclosure

Preliminary report on the rescue excavation at Szurdokpüspöki - Hosszú-dúlö II-III. (M21 site No. 6-7)

Kristóf FüLÖP - Gábor VÁcZI

Preliminary report on the excavation of a new Late Bronze Age cemetery

from fobbágyi (North Hungary)

Lőrinc TimÁr - Zoltán CzAJLik - András BöDőcs - Sándor PuszTA

Geophysical prospection on the Pâture du Couvent (Bibracte, France). The campaign of 2014

Dávid BARtus - László Borhy - Gabriella Delbó - Emese SzÁmadó

Short report on the excavations in the civil town of Brigetio (Szőny-Vásártér) in 2014

Dávid BARTus - László BorHy - Emese SzÁMADó

A new Roman bath in the canabae of Brigetio

Short report on the excavations at the site Szőny-Dunapart in 2014

Dávid BARTus - László Borhy - Zoltán CzAjlik - Balázs Holl -

Sándor PuszTA - László RuPNiK

Topographical research in the canabae of Brigetio in 2014

Zoltán CZAJLIK - Sándor BERECKI - László RUPNIK

Aerial Geoarchaeological Survey in the Valleys of the Mureș and Arieș Rivers (2009-2013)

Maxim MoRDovin

Short report on the excavations in 2014 of the Department of Hungarian Medieval

and Early Modern Archaeology (Eötvös Loránd University, Budapest)

Excavations at Castles Čabrad' and Drégely, and at the Pauline Friary at Sáska

\section{Thesis Abstracts}

Piroska Csengeri

Late groups of the Alföld Linear Pottery culture in north-eastern Hungary

New results of the research in Borsod-Abaúj-Zemplén County

Ádám Bíró

Weapons in the 10-11th century Carpathian Basin

Studies in weapon technology and methodology - rigid bow applications and southern import

swords in the archaeological material

Márta DARÓcZI-SzABó

Animal remains from the mid 12th-13th century (Árpád Period) village of Kána, Hungary

Károly BELÉNYESY

A 15th-16th century cannon foundry workshop in Buda

Craftsmen and technology of cannon moulding and the transformation of military technology

from the Renaissance to the Post Medieval Period 
István RINGER

Manorial and urban manufactories in the 17th century in Sárospatak

\section{BIBLIOGRAPHY}

László BORHY

565

Bibliography of the excavations in Brigetio (1992-2014) 


\title{
Animal remains from the mid 12th-13th century (Árpád Period) village of Kána, Hungary
}

MÁrta DARÓCZI-SzABó

martidsz@gmail.com

\begin{abstract}
PhD thesis submitted in 2014 to the Archaeology Doctoral Programme, Doctoral School of History, Eötvös Loránd University, Budapest under the supervision of László Bartosiewicz.
\end{abstract}

\section{The research and its objectives}

A village dated to the second half of the period of the Árpád Dynasty (11th-13th century $\mathrm{AD}$ ) stands in the center of my research. This site is unique in Hungary regarding the completeness of its excavation. The late Árpád Period village of Kána came to light in the 11th district of Budapest, during the excavations preceding the building of the present-day Újbuda-Tóváros (previously called Kőérberek-Tóváros) residential park. The archaeological excavation was led by the archaeologists of the Budapest History Museum between autumn 2003 and summer 2005. The excavated area measuring 220,000 square metres yielded finds from different archaeological periods between the Neolithic and the Middle Ages. Prehistoric field works were led by László András Horváth and Gábor Szilas, while those of the Migration Period by Attila Horváth and Anita Korom. Excavations concerning the Middle Ages were directed by György Terei. The plans of the residential park completely covered the Árpád Period village of Kána, which could therefore be fully excavated on a total of 16 acres. Archaeologists brought to light the parish church and the surrounding cemetery with a total of 1077 graves, as well as 198 semi-subterranean houses and four large store buildings, a number of open air ovens and hundreds of storage and refuse pits. Trenches separating the buildings were also discovered during the field work. Based on the finds, the inhabitation of the village began during the middle of the 12th century, but from the middle of the 13th century a slow depopulation began. Objects datable to the beginning of the 14th century occurred only sporadically. The finds (the church built using ashlar stones, the highstandard stone carvings, the large number of stone-lined graves in the settlement as well as the quantity and quality of glassware, the coins, the ornamented artefact for attire, and the many good-quality iron artefacts recovered at the settlement) suggest the unusual richness of the population compared to the rural nature of the settlement. ${ }^{1}$

The archaeological exploration of the nearby Kána Abbey was carried out by Katalin H. Gyürky, who excavated the ruins of the late benedictine monastery between 1981 and $1989 .{ }^{2}$ The relation between the abbey and the village seems evident in the light of historical as well as archaeological data. Although no direct written references are known to the village,

1 DANISS 2005; Földesi 2005; Gyöngyössy 2011; GYőző 2005; HANCZ 2005; 2009; HoRVÁth ET AL. 2005; 2006; 2012; Horváth - Terei 2009; LÁszló 2005; Terei 2004; 2005a; 2005b; 2006; 2010; Terei in press; Terei et Al. 2005; TereI Horváth 2007a; 2007b; Terei - VARgha 2013; VARgha 2012.

2 H. GYÜRKY 1989; 1991; 1992; 1993; 1996. 
from the 1325 land description of the village of Nevegy we can not only identify the abbey, but the text also reveals that the village of Kána was located within the lands of the abbey. Therefore its population lived under the rule of the parochial lord. The relation between the abbey and the village is also illustrated by similar burial customs: $40 \%$ of the graves from the village were lined with decorative fretwork stones, and many similar graves were found in the abbey as well.

The reasons of the depopulation of the village are unknown, but it might be related to the expansion of viticulture which caused the decrease of plough-lands. As the lord of the abbey ruled over the population, it can also be assumed that the abandonment of the village was related to his decisions.

The completeness of the excavation resulted in an abundance of finds, which was also shown in the exceptionally high number of animal remains. The archaeozoological analysis therefore had two aims: on the one hand to explore animal use by the late residents of the village, on the other the investigation of how well do phenomena observed on a large scale in Kána fit the economic and cultural image „typical” of the Árpád Period.

\section{Results}

A total of 19,529 animal remains came to light from Árpád Period features which, even regardless of fragments that could not be identified on a species or at least family level, results in a substantial assemblage consisting of over twelve thousand pieces. The majority of bones came from domestic animals, mainly from cattle. Small stock, represented by sheep and/or goat and pig, followed far behind. The ratio of dog and horse remains was relatively high, which, in the case of the first can be explained by the presence of more-or-less intact skeletons found in special features. The complete dog skeletons originate from different sized individuals, indicative of a number of medieval forms, but these (except for a greyhound-like individual based on its skull conformation) can not be referred to modern breeds because of the high genetic „plasticity” resulting from the high reproduction rate of dogs. The rest of the domestic species (donkey, hen, goose and cat) are represented by far fewer fragments. Although the donkey bones from Kána cannot be regarded as unique finds, they are not too frequent in Árpád Period deposits.

The ratio of wild animals can be considered low, in particular if we set aside smaller species which may be intrusive in archaelogical features as a result of „taphonomic gain” (e. g. hamster, ground-squirrel, frogs and tortoise). Shed antlers of red and roe deer also forms a different category as they could be hand-collected by villagers. Remains of red deer, wild boar, hare and fox may be considered those of hunted animals, the latter supposedly also having been hunted for fur. There were two bones that might have originated either from aurochs or bison, but neither of those could be dated undoubtedly to the Árpád Period. Among wild birds, in addition to those found more frequently in Árpád Period deposits (partridge, quail and mallard), it was the first time when gyrfalcon could be identified. Bones of raptors such as sparrow-hawk, goshawk and golden eagle were usually found in high-status (royal, parochial and military) deposits until now, none from rural assemblages. On the tibia of the golden eagle a cutmark could be observed raising the question whether it should be regarded as kitchen refuse, while the remains of the other three diurnal birds of prey may be 
indicative of falconry. Although the remains of carp, pike and catfish identified are the most frequently encountered fish species in medieval deposits in Hungary, the small sized fish bones are underrepresented in hand-collected assemblages. Shells of riverine mussels were also found in large numbers. One feature yielded a poorly preserved fragment of a scallop, which may be interpreted as a fossil find. ${ }^{3}$

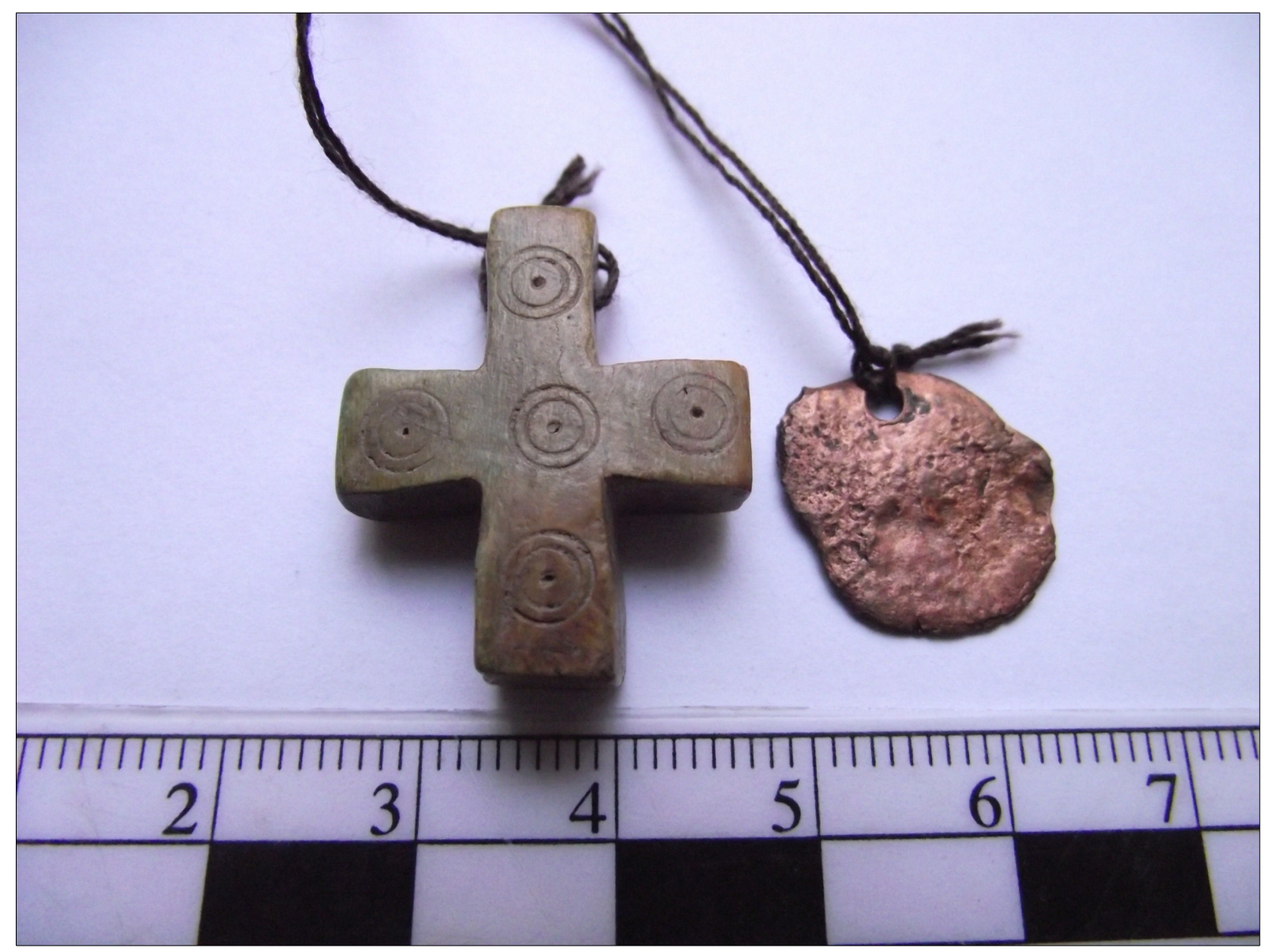

Fig. 1. Antler medallion with a small bronze plate from a grave of a child (Photo: M. Daróczi-Szabó).

Basically two types of exploitation of the animals can be reckoned with: primary and secondary. The first includes slaughter i.e. the consumption of meat and fat, as well as the usage of bones and skin. Secondary exploitation means the production of seasonally renewable animal goods such as milk, fleece, and eggs, or those continuously available (workpower, manure). However, the presentation of these latter forms of exploitation yields little archeozoological evidence. It could therefore be discussed mostly on the basis of contemporaneous and later written sources and ethnographic parallels.

Through the investigation of the archaeozoological assemblage we gain insight mostly in the primary exploitation of animals, most of all the meat consumption customs of the villagers. Based on the animal bones the people of Kána ate mainly beef, mutton and pork, completed with meat from the aforementioned domestic poultry, wild mammals (red deer, wild boar and hare) and fish. Naturally, in addition to meat, we can suppose the consumption of fats and tallow, dairy products and egg, although from these only the remains of eggs

3 DARÓcZi-SzABó 2008. 
can be archaeologically identified. Although horses were kept mainly for their secondary (riding and traction) use, in some cases I could find cut and butchered bones coming from meaty parts of the animal, indicative of the occasional consumption of horse meat. Remains of domestic animals also characterize animal keeping by the locals, in which (based on both the number of identified fragments and the number of individuals) ruminants played the greatest role.

There is only indirect evidence concerning the use of animal skins, hides and fur: on one hand we can study cutmarks observed on bones unrelated to meat consumption (e.g. on the dry limb bones at the end of extremities, or cutmarks on the bones not meat-purpose animals). The other type of finds is even more indirect, related to leatherware such as beltbuckles or horse-harnessing, suggesting the use of animal raw materials.

Beyond their roles in alimentation and clothing, tools made from animal remains can also be counted as primary uses. Through bone manufacturing we can get a glimpse into the material culture of the Árpád Period population. Based on the crude execution of bone and antler tools it seems that these artifacts were made at home for domestic usage, and the raw material was gained from ordinary food refuse. Among bone tools there were skates, different toys, needle holders, bone anvils and other objects of everyday life. Sometimes antlers were worked into buckles and simple adornments. In one case, a carefully elaborated, highly worn, cross- shaped medallion came to light from the grave of a child together with a small bronze plate (Fig. 1). Unlike bone tools made from household refuse, antler as a raw material was obtained either by hunting stags, or simply collecting pieces of shed antler. A medallion made from mussel shell was also recovered, but it was more rudimentary in shape than the cross-shaped pendant. On the edge of some shells traces of abrasion were observed, these specimens may have been used as spoons or scrapers. Based on the known medieval parallels, the (possibly fossil) scallop fragment may well have been a pilgrim-badge, but in lack of traces of shaping or usage this assumption can not be proven on the basis of the small fragment. In addition to the rudimentary, home made tools sometimes more carefully elaborated pieces appeared in the material, for example a lathe-turned needle-holder (Fig. 2) and another turned piece with unknown function, which, presumably, came to the village as imported ware.

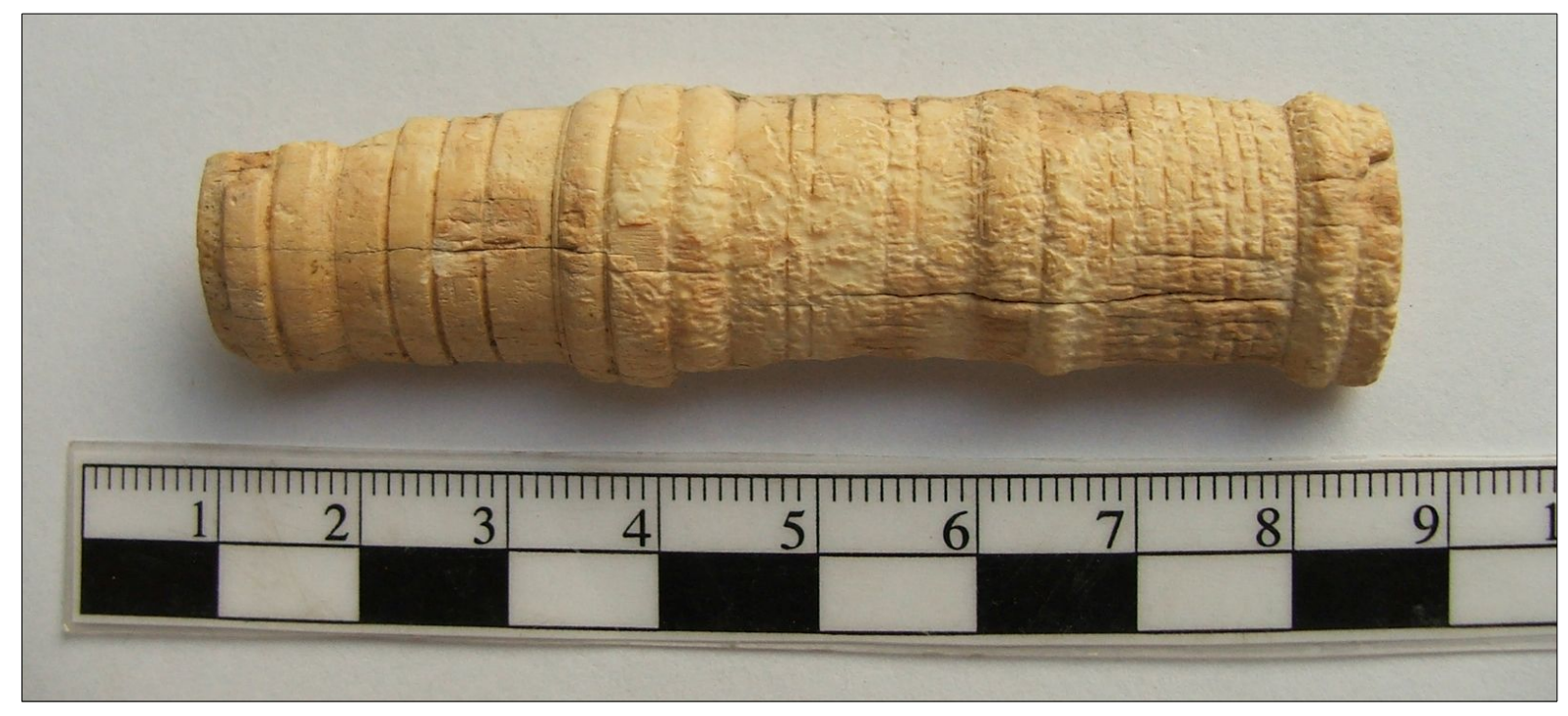

Fig. 2. Lathe-turned needle-holder (Photo: M. Daróczi-Szabó). 
Although animal sacrifices can also be regarded as primary usages, because of the ritual subject they somehow differ from the everyday slaughter. In Kána 21 pots buried for ritual purposes were found, 15 of which contained sacrificed animals. Although archaeologists had found traces of similar phenomena before, until now evidence for this tradition has never been discovered in such large numbers. Pots buried upside down in houses can be regarded as building sacrifices (Fig. 3), but in case of those coming from pits and trenches we can also reckon with the possibly apotropaic functions. The sacrificed animals were often accompanied with iron objects. These were in most cases nails, but in one case the pot contained a needle and a knife. The explanation can be sought in the protective role of iron cutting objects, a widespread, ancient belief. Apart from the chicken bones and eggs usually found under pots at other medieval sites, the pots from Kána contained remains of species, namely dogs and cats, barely known in such ritual contexts. In five pots pike bones were found, which for the time being have not been known in such a role either. The finds testify that the custom of construction sacrifice survived well alongside Christianity, which is not only shown by the survival of elements of the broader tradition in the 20th century as well, but also by the fact that similar sacrifices were found in parochial buildings not only in the Carpathian Basin, but all over Europe. ${ }^{4}$

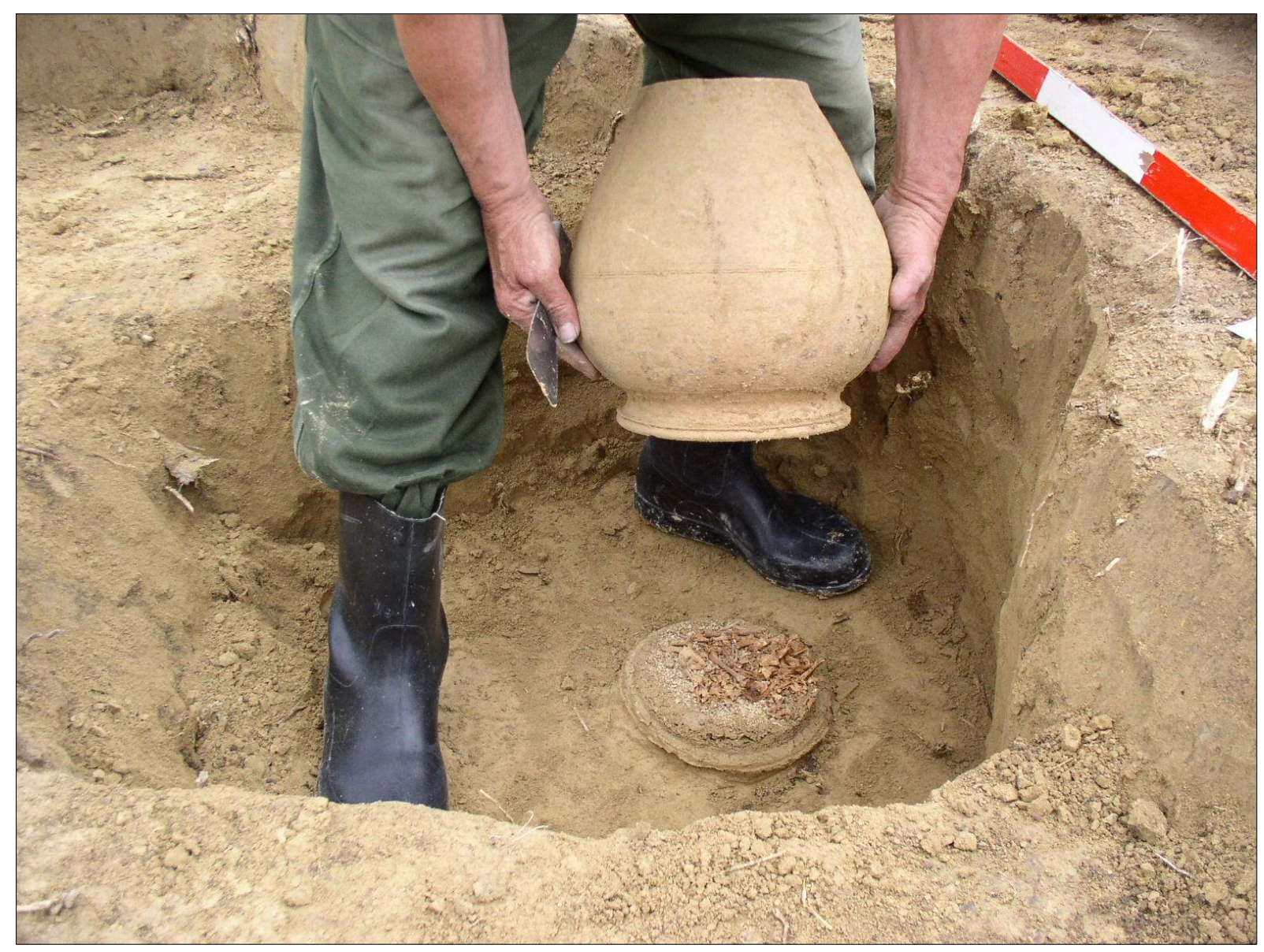

Fig. 3. Pot with animal sacrifices from a house (Photo: Gy. Terei). 
The archaeological recognition of secondary exploitation is much more difficult than those of primary uses, as its evidence usually remains indirect with the exception of eggshells. For example, a number of pathological deformities (e.g. periostosis and periarthritis on legs, haematoma, diseases on vertebrae) could be observed on cattle and horse bones. These may be associated with the increasing use of the animal in work, indirectly implying yoking for transport as well as tillage and riding. Although among the remains of cattle the bones of cows dominated, the presence of probable draught oxen could also be detected.

In the absence of sophisticated laboratory procedures (fat residue analysis), proving cow-, sheep-, goat- and horse milk consumption can also be very difficult in the archaeological material. However, „depressions”, namely bone absorbtions on the horn cores of two ewes may be indirectly related to overmilking. Dams sometimes mobilize calcium from their own bones in order to assure the optimal composition of their milk, which can result in such deformities.

The use of fleece, furs and feathers can also be reconstructed only using indirect evidence: the first formed part of the attire, while feathers were an indispensable element of arrows (evidenced by arrowheads found at Kána), and may have served decorative purposes as well.

Manure may be used in various ways. Its primary role must have been the enrichment of plough-lands, but based on etnographic parallels, we can reckon with its uses as fuel or building material. In addition to vegetal substances, the excrement of dogs played a technical role in the tanning of skins and hides. Manure is usually not preserved. However, a piece of petrified dog excrement came to the surface from one of the pits, which owes its preservation to the increased mineral content resulting from intense bone consumption by the dog.

Dogs (in addition to their role as sacrificial animals) had an important role to play in the life of medieval Kána. Their secondary uses included keeping guard dogs, herding and hunting. However, while guarding their territory is instinctive to most dogs, some breeds can be better used for animal driving or hunting than others even if modern breeds cannot be directly equated with medieval forms. A greyhound-shaped dog from Kána supposedly served as a hunting dog. Similar skeletons are known from five other Árpád Period sites ${ }^{5}$ and written sources also refer to serfs keeping hounds. ${ }^{6}$

Not counting the individual whose remains were found in a sacrificial pot, the function of cats was supposedly limited on protecting the grain and stores from rodents.

Árpád Period falconry was so far known mainly from written and iconographic sources. Osteological evidence has been rare. This can be explained with that the majority of the falconers' equipment was made of organic material. Based on the remains of diurnal birds of prey found in Kána it can be presumed that some villagers were involved with this form of hunting.

\section{Summary}

Due to the complete recovery and unique richness of the archaeological material from Kána, this site has an exceptional role to play in the research of Árpád Period villages. The archaeozoological analysis offers insight into the various relationships between the inhabitants of the settlement and the fauna of the surrounding natural and economic environment. 
Animal bone materials from the Árpád Period village of Kána were dominated by cattle remains, while the contributions of poultry and wild animals were low. Other species of livestock (pig, sheep and/or goat and even horse) played varying roles in the diet. Dog and cat were not eaten but sometimes used in rituals. The composition of animal bone assemblages is influenced by a number of factors such as sample size, fragmentation and the number of complete skeletons impacting the species ratios, geographical environment, the types of the excavated features. These all need to be considered prior to the reconstruction of dietary customs and other forms of animal exploitation. Due to its large size and immense diversity, the animal bone assemblage from Kána enriches our knowledge concerning animal exploitation in early medieval Hungary, offering several previously unknown details.

Although animal remains yielded valuable information in themselves, they can be best evaluated in light of the complete archaeological material and documentary sources.

\section{References}

BöKÖNYI, S. 1974: History of domestic mammals in Central and Eastern Europe. Budapest.

DANIss, Gy. 2005: Kána megmentése. National Geographic 2005. június, 90-107.

DARóczi-SzABó, M. 2008: Állattartás középkori falvainkban. In: Kubinyi, A. - LASZlovszky, J. - SzABó, P. (eds.): Gazdaság és gazdálkodás a középkori Magyarországon: gazdaságtörténet, anyagi kultúra, régészet. Budapest, 99-101.

Daróczi-Szabó, M. 2010: Pets in pots: Superstitious belief in a medieval Christian (12th-14th c.) village in Hungary. In: Campana, D. - Crabtree, P. - de France, S. D. - Lev-Tov, J. - Choyke, A. M. (eds.): Anthropological Approaches to Zooarchaeology: Colonialism, Complexity, and Animal Transformations. Oxford, 244-249.

Daróczi-Szabó, M. - Terei, Gy. 2011: Szájával lefele fordított edények és tartalmuk az Árpád-kori Kána faluból. Budapest Régiségei 44, 198-226.

FöldEsI, Sz. 2005: Megjegyzések a kánai középkori őrlőkövekről. In: KisfaLudI, J. (ed.): Régészeti kutatások Magyarországon 2004. Budapest, 54-55.

GyöNGyössy, M. 2011: Pénzhasználat 12. századi falvainkban. In: Kolozsı, B. - SzILÁGYI, K. A. (eds): Sötét idők falvai. 8-11. századi települések a Kárpát-medencében. Debrecen, 687-700.

Győző, E. 2005: Kána falu templomának kőfaragványai. In: Kisfaludi, J. (ed.) Régészeti kutatások Magyarországon 2004. Budapest, 56-57.

H. GyüRKy, K. 1989: Előzetes jelentés a „Kánai apátság” kolostorának feltárásáról. Archaeologiai Értesitó 116, 111-118.

H. Gyürky, K. 1991: Die Abtei von Kána. In: Biegel, G. (ed.): Budapest im Mitteralter. Braunschweig, 404-408.

H. Gyürky, K. 1992: A kánai apátság régészeti kutatása 1983-1989 között. Budapest Régiségei 29, $225-228$.

H. Gyürкy, K. 1993: A kánai apátság. Régészeti emlékek Budapest XI. kerületében. XI. kerületi füzetek 2, 37-44.

H. GyÜRкy, K. 1996: A Buda melletti kánai apátság feltárása. Budapest.

Hancz, E. 2005: Kána falu üvegleletei. In: Kisfaludi, J. (ed.): Régészeti kutatások Magyarországon 2004. Budapest, 50-53. 
HANCZ, E. 2009: A Budapest, Kőérberek-Tóváros lakópark területén végzett megelőző feltárás során előkerült üvegleletek. In: SzABó, Á. (ed.): 'Ripam omnen quaesivit' Ünnepi tanulmányok prof. Visy Zsolt 65. születésnapjára tanítványaitól. Pécs-Paks, 81-100.

Horváth, A. - Terei, Gy. 2009: Kána falu vasleletei. In: Nagy, Z.- Szulovszky, J. (eds): A vasmúvesség évezredei a Kárpát-medencében. Szombathely, 105-117.

Horváth, L. A. - Korom, A. - Terei, Gy. - Szilas, G. - Reményi, L. 2005: Előzetes jelentés az épülő Kőérberek-Tóváros-Lakópark területén folyó régészeti feltárásról. Aquincumi Füzetek 11, 137167.

Horváth, L. A. - Horváth, M. A. - Terei, Gy. 2006: Előzetes jelentés a Bp. XI. ker. KőérberekTóváros-Lakópark lelőhelyen, 2005. évben elvégzett régészeti feltárásokról. Aquincumi Füzetek $12,159-165$.

Horváth, Z. - Mindszenty, A. - Terei, Gy. 2012: Az Árpád-kori Kána falu objektumaiban talált kőzettípusok és azok lehetséges származási helyei. In: Petkes, Zs. (ed.): Hadak útján XX. Népvándorláskor Fiatal Kutatóinak XX. Összejövetelének konferenciakötete. 2010. október 28-30. Magyar Nemzeti Múzeum. Budapest - Szigethalom, 313-326.

LÁszLó, O. 2005: Kérdések és feladatok a kánai temető antropológiai feldolgozásával kapcsolatban. In: Kisfaludi, J. (ed.) Régészeti kutatások Magyarországon 2004. Budapest, 58-60.

MATOLCsI, J. 1982: Állattartás őseink korában. Budapest.

SzABó, I. 1969: A középkori magyar falu. Budapest.

Terei, Gy. 2004: Kána. Egy középkori falu Budapest határában. Magyar Múzeumok 2004/3, 22-24.

Terei, Gy. 2005a: Előzetes jelentés a Kőérberek-Tóváros - Lakópark területén folyó Árpád-kori falu feltárásáról. In: KisfaLudi, J. (szerk.) Régészeti kutatások Magyarországon 2004. Budapest, 34-72.

TEREI, Gy. 2005b: Kőérberek-Tóváros - Lakópark. In: Zsidi, P. (ed.): Kincsek a város alatt. Budapest régészeti örökségének feltárása, 1989-2004. Budapest, 88-99.

TereI, Gy. 2006: Kána falu Árpád-kori temploma és temetője. Régészeti értékeink 16. Budapest.

TereI, Gy. 2010: Az Árpád-kori Kána falu Budapest határában. In: Kovács, Gy. - Benkő, E. -Feld, I. (eds.): Középkori régészetünk újabb eredményei és időszerü feladatai. Budapest, 81-111.

TEREI, Gy. In press: Az Árpád-kori Kána falu kerámiamúvessége.

Terei, Gy. - Horváth, L. A. - Korom, A. - Szilas, G. 2005: Budapest, XI. Kőérberek, Tóváros-lakópark. In: Kisfaludi, J. (ed.) Régészeti kutatások Magyarországon 2004. Budapest, 196-197.

Terei, Gy. - Horváth, A. 2007a: Az Árpád-kori Kána falu vasleletei I. (The iron finds from Period II at the Árpádian village at Kana I). Communicationes Archaeologicae Hungariae, 215-245.

Terei, Gy. - Horváth, A. 2007b: Az Árpád-kori Kána falu vasleletei II. (The iron finds from Period II at the Árpádian village at Kana II). Budapest Régiségei 41, 153-192.

Terei, Gy. - Vargha, M. 2013: Madár alakú bronzcsat az Árpád-kori Kána faluból. Budapest Régiségei 46, 151-166.

VArgha, M. 2012: Kána falu temetóje. Unpublished MA-thesis. Budapest.

VöRös, I. 1990a: Szabolcs ispánsági székhely Árpád-kori állatcsontleletei. A nyíregyházi fózsa András Múzeum Évkönyve 1984-1986, 165-188.

VöRös, I. 1990b. Kutyaáldozatok és kutyatemetkezések a középkori Magyarországon I. Folia Archaeologica 41, 117-146. 